\title{
КОНСТИТУЦИОННЫЕ ПРАВА И СВОБОДЫ: СУДЕБНЫЕ И АДМИНИСТРАТИВНО-ПРАВОВЫЕ СРЕДСТВА ОБЕСПЕЧЕНИЯ (РОССИЙСКИЙ И ЕВРОПЕЙСКИЙ ОПЫТ)
}

\begin{abstract}
Аннотация: В статье рассматриваются проблемы соотношения таких функций судебных органов конституционного контроля как правовая охрана конституции и защита конституционных прав и свобод человека и гражданина. На основании анализа ряда решений Конституционного Суда Российской Федерации, а также органов конституционной юстиции государств Центральной и Восточной Европы сделан вывод о том, что в зачастую данные органы изменяют содержание конституционных норм. В частности, конституционные суды дают расширительное толкование конституционных норм, закрепляющих право на жизнь, вводят прямой запрет смертной казни и эвтаназии даже при отсутствии указания на это в конституционных нормах. В решениях судебных органов конституционного контроля также может изменяться и субъект конституционных прав (устанавливаться право на жизнь для нерожденного ребенка). Методологическую основу статьи составили современные достижения теории познания. В процессе исследования применялись общефилософский, теоретический, общефилософркие методы (диалектика, системный метод, анализ, синтез, аналогия, дедукция, наблюдение, моделирование), традиционно правовые методы (формально-логический), а также методы, ис-пользуемые в конкретно-социологических исследованиях (статистические, экспертные оценки и др.). Вместе с тем, анализ практики как Конституционного Суда РФ, так и конституционных судов иных государств Центральной и Восточной Европы показывает, что в процессе осуществления этой основной цели данные органы не только делают итоговый вывод о конституционности рассматриваемого правового акта, но и формируют собственное отношение к рассматриваемым правовым проблемам, то есть свою правовую позицию, содержащую толкование конституционных норм, закрепляющих права и свободы человека и гражданина. При этом, судебные органы конституционного контроля уточняют смысл и содержание конституционных положений применительно к сфере общественной жизни, урегулированной законом или иным нормативным правовым актом, конституционность которого проверяется. Общепринятым в настоящее время в науке конституционного права России и государств Центральной и Восточной Европы является взгляд на правовую позицию конституционного суда как на обязательное толкование конституционных норм.
\end{abstract}

Ключевые слова: права, свободы, жизнь, суд, защита, охрана, орган, контроль, закон, обеспечение.

$\mathrm{O}$ дной из основных задач деятельности судебных органов конституционного контроля как в Российской Федерации, так и в государствах Центральной и Восточной Европы, является защита основных прав и свобод человека и гражданина, закрепленных в конституциях данных государств. Указанная задача, непосредственно закрепляется в ч. 1 ст. 3 Федерального конституционного закона от 21 июля 1994 г. № 1-ФКЗ (в ред. от 4 июня 2014 г.) “О Конституционном Суде Российской Федерации"1, преамбуле Закона Венгер-

Федеральный конституционный закон от 21 июля 1994 г. № 1-ФК3 (в ред. от 4 июня 2014 г.) «О Конституционном Суде Российской Федерации» // Собрание законодательства РФ. 1994. № 13 . Ст. 1447. ской Республики № CLI 2011 «О Конституционном Суде» ${ }^{2}$, а также на конституционном уровне - в ст. 126 Конституции Словацкой Республики от 1 сентября 1992 г. № 460/1992 Z.z.; ст. 160 (ч. 3) Конституции Республики Словения ${ }^{4}$ ст. 125 (абз. 4) Конституции

\footnotetext{
2 Закон Венгерской Республики № CLI 2011 «О Конституционном Суде» / Act № CLI. of 2011 on the Constitutional Court // Официальный интернет-сайт Конституционного Суда Венгерской Республики. http://www.mkab.hu/rules/act-on-the-cc.

Конституция Словацкой Республики от 1 сентября 1992 г. № 460/1992 Z.z. // Конституции государств Европы. В 3 т. / Под общ. ред. Л.А. Окунькова. М., 2001. Т. 3. С. 128-154.

4 В Конституции Республики Словения установлено ограничение использования данного права - исчерпание всех иных способов защиты.
} 
Республики Хорватия от 22 декабря 1990 г.; ст. 86, (ч. 1, п. «d») Конституции Чешской Республики ${ }^{6}$. При этом, только в Конституции Республики Польской (ст. 79, ч. 1) право на обращение с жалобой в Конституционный Трибунал закреплено в качестве конституционного права7. Однако, главной целью учреждения и функционирования судебных органов конституционного контроля как в Российской Федерации, так и в иных постсоциалистических государствах была и остается защита основного закона соответствующей страны, обеспечение его верховенства и реализации в как отношениях между государством, обществом и человеком, так и в иных конституционных правоотношениях.

Вместе с тем, анализ практики как Конституционного Суда РФ, так и конституционных судов иных государств Центральной и Восточной Европы показывает, что в процессе осуществления этой основной цели данные органы не только делают итоговый вывод о конституционности рассматриваемого правового акта, но и формируют собственное отношение к рассматриваемым правовым проблемам, то есть свою правовую позицию, содержащую толкование конституционных норм, закрепляющих права и свободы человека и гражданина. При этом, судебные органы конституционного контроля уточняют смысл и содержание конституционных положений применительно к сфере общественной жизни, урегулированной законом или иным нормативным правовым актом, конституционность которого проверяется. Общепринятым в настоящее время в науке конституционного права России и государств Центральной и Восточной Европы является взгляд на правовую позицию конституционного суда как на обязательное толкование конституционных норм ${ }^{8}$.

Зачастую, толкование конституционной нормы, содержащееся в решении судебного органа

\footnotetext{
5 Конституция Республики Хорватия от 22 декабря 1990 г. // Конституции государств Европы. В 3 т. / Под общ. ред. Л.А. Окунькова. М., 2001. Т. 3. С. 435-476.

6 Конституция Чехии (Чешской Республики) от 16 декабря 1992 г. // Конституции государств Европы. В 3 т. / Под общ. ред. Л.А. Окунькова. М., 2001. Т. 3.С. 435-451.

7 Конституция Республики Польской от 2 апреля 1997 г. // Конституции государств Европы. В 3 т. / Под общ. ред. Л.А. Окунькова. М., 2001. Т. 2. С. 686-732.

8 См., например: Hollander. P. The Role of Czech Constitutional Court: Application of the Constitution in Case Decision of Ordinary Courts // Parker School journal of East European law. 1997. Vol. 4. P. 445-465.
}

конституционного контроля не только конкретизирует ее содержание, но может и изменить его. Наиболее ярко такой характер правовых позиций конституционных судов, определяющих развитие законодательства и правоприменительной практики, проявляется в их решениях в защиту конституционного права на жизнь.

Одной из главных сфер общественной жизни, в которых право на жизнь имеет специальное применение, является решение вопроса об установлении в законе высшей меры наказания. В течение социалистического периода, смертная казнь использовалась как в Российской Федерации, так и в государствах Центральной и Восточной Европы. Все уголовные кодексы соответствующих государств содержали широкие каталоги преступлений, наказуемых смертной казнью 9 . После присоединения к Совету Европы большинство государств Центральной и Восточной Европы отменило смертную казнь; этому, в значительной степени, способствовала ратификация Протокола № 6 к Европейской конвенции о защите прав человека и основных свобод относительно отмены смертной казни ${ }^{10}$. Ясно, что, перед лицом широкой общественной поддержки, направленной на отмену смертной казни в этих странах ${ }^{11}$, потребность реализовывать международные стандарты защиты прав человека была решающим фактором для отказа от законодательного закрепления смертной казни ${ }^{12}$.

В при этом, в большинстве государств Центральной и Восточной Европы смертная казнь явно не упомянута в конституциях, но эта санкция исключена из уголовного законодательства. В трех конституциях - ст. 24 Конституции Республики Беларусь, ст. 24 Конституции Республики Молдова, ст. 20 Конституции Российской Федерации 1993 г. - содержится упоминание о смертной казни как «исключительной мере наказания за особо тяжкие преступления».

\footnotetext{
9 См., подробнее: Fijalkowski A. The Abolition of the Death Penalty in Central and Eastern Europe // Tilburg Foreign Law Review. 2001. Vol. 9. Р. 72-73.

10 Протокол № 6 к Европейской конвенции о защите прав человека и основных свобод относительно отмены смертной казни (ETS № 114). Подписан в г. Страсбурге 28 апреля 1983 г. // Действующее международное право. Т. 2.- М.: Московский независимый институт международного права, 1997. С. $130-132$.

11 См.: Schwartz H. The Struggle for Constitutional Justice in Post-Communist Europe, Chicago, 2000. P.89.

12 См.: Fijalkowski A. The Abolition of the Death Penalty in Central and Eastern Europe. P. 63.
} 
При этом, в решениях конституционных судов Албании, Литвы, Венгрии и Украины содержится явное и недвусмысленное предписание законодателю исключить смертную казнь из числа уголовно-правовых санкций. Так, например, в решении Конституционного Суда Венгерской Республики № 23/1990 уголовно-правовые и уголовно-процессуальные нормы о смертной казни признавались противоречащими принципу уважения человеческого достоинства, поскольку они разрешали «полное и непоправимое уничтожение жизни, человеческого достоинства личности или прав, их гарантирующих» ${ }^{13}$. В то же время ч. $1 \S 54$ Конституции Венгерской Республики 1949 г. подразумевала допустимость смертной казни, поскольку содержала запрет только на «произвольное» лишение жизни. Как впоследствии заметил Л. Шольом, решение Конституционного Суда «свидетельствовало о действительной юридической силе и значении конституционного контроля и потрясло ... Парламент, а также широкую публику». Это «потрясение» было тем более очевидно, поскольку в то время приблизительно 70 \% граждан Венгрии поддерживали смертную казнь. Как указывал Л. Шольом, «общие ценности, на которых основывалось решение, были установлены вне Конституции» ${ }^{14}$. Интересно, что судья А. Шмидт, проголосовавший против данного решения Конституционного Суда, предположил, что полномочие отменить смертную казнь посредством внесения конституционных поправок принадлежит Парламенту Венгрии ${ }^{15}$, однако, большинство судей отвергли его правовую позицию.

Указание на нарушение нормой ст. 105 Уголовного кодекса Литовской Республики конституционного принципа достоинства личности содержится и в постановлении Конституционного Суда Литвы от 9 декабря 1998 г., в котором, в частности, указывается, что закрепление в уголовном законодательстве смертной казни в качестве меры уголовного наказания означает «отказ рассматривать осужденного как человека и выражает отношение

13 Решение Конституционного Суда Венгерской Республики № 23/ 1990 от 31 октября 1990 г. / Decision No. 23/1990 of 31 October 1990 // East European Case Reporter of Constitutional Law. 1994. Vol. 1. P. 177-205.

14 См.: Solyom L., Brunner G. Constitutional Judiciary in a New Democracy: The Hungarian Constitutional Court. P. 125.

15 Особое мнение судьи Конституционного Суда Венгерской Республики А. Шмидта. / Dissent by A. Schmidt // East European Case Reporter of Constitutional Law. 1994. Vol. 1. P. 204-205. к нему как к предмету, подлежащему уничтожению государством, что само по себе нарушает конституционное положение об уважении человеческого достоинства» ${ }^{16}$.

Конституционные суды Албании и Украины, делая вывод о неконституционности смертной казни, вообще не основывались на конституционных положениях. Аргументация соответствующих решений, как указывает К. Коротеев ${ }^{17}$, лежит в политической сфере. Так, Конституционный Суд Албании прямо указал на то, что «... политические обязательства, принятые Республикой Албанией, основываются на условиях, определенных Советом Европы с целью отмены смертной казни... поэтому ... следует отменить высшую меру наказания, опасаясь политических санкций в рамках этой организации...» ${ }^{18}$. Близкие доводы в обоснование неконституционности смертной казни как меры наказания привел и Конституционный Суд Украины в своем решении № 11-рп от 29 декабря 1999 г. $^{19}$

Таким образом, в решениях указанных конституционных судов смысл конституционной нормы об охране законом жизни человека (ст. 21 Конституции Республики Албании, ст. 19 Конституции Литовской Республики) или о запрете произвольного лишения жизни (§ 54 Конституции Венгерской Республики 1949 г., ст. 27 Конституции Украины) был изменен, в содержание права на жизнь включен аб-

16 Постановление Конституционного Суда Литовской Республики о соответствии смертной казни, предусмотренной санкцией статьи 105 Литовской Республики Уголовного кодекса, Конституции Литовской Республики от 9 декабря 1998 г. / Ruling of the Constitutional Court of the Republic of Lithuania on the compliance of the death penalty provided for by the sanction of Article 105 of the Republic of Lithuania Criminal Code with the Constitution of the Republic of Lithuania of December 9, 1998 // Официальный интернет-сайт Конституционного Суда Литовской Республики. http://www.lrkt.lt/ dokumentai/1998/n8a1009a.htm.

17 См.: Коротеев К. Мотивировки решений конституционных судов о смертной казни // Сравнительное конституционное обозрение. 2008. № 5 (66). С. 136.

18 Решение Конституционного Суда Республики Албании № 65 от 10 декабря 1999 г. о конституционности высшей меры наказания // Интернет-сайт Конституционного Суда Республики Албании. http://www.gjk.gov.al/web/Decisions_92_2.php.

19 Рішення Конституційного Суду України № 11-рп/99 від 29 грудня 1999 р. у справі за конституційним поданням 51 народного депутата України щодо відповідності Конституції України (конституційності) положень статей $24,58,59,60$, 93, 190-1 Кримінального кодексу України в частині, що передбачає смертну кару як вид покарання (справа про смертну кару) // Интернет-сайт Конституционного Суда Украины. http://www.ccu.gov.ua/doccatalog/document?id=9347. 
солютный запрет на установление смертной казни как меры наказания и ее применение.

Конституционный Суд РФ в постановлении от 2 февраля 1999 г. № 3-П и определении от 19 ноября 2009 г. № 1344-0-Р постановил, что «наказание в виде смертной казни назначаться не может ...» 20 ; и введение суда с участием присяжных заседателей на всей территории России (предусмотренное чт. 2 ст. 20 Конституции РФ) не открывает возможность применения смертной казни ${ }^{21}$. Таким образом, указанное толкование ст. 20 Конституции РФ значительно изменяет буквальный смысл указанной нормы.

Второй важной проблемой, при решении которой конституционные суды обращаются к конституционному праву на жизнь, является проблема абортов. Ни одна из конституций государств Центральной и Восточной Европы явно не запрещает аборт или планирование семьи; они просто заявляют, что жизнь человека находится под государственной защитой. Исключение представляют лишь ч. 1 ст. 6 Хартии Чешской Республики о правах человека и ч. 1 ст. 15 Конституции Словацкой Республики.

Законодательство об абортах рассматривали 2 конституционных суда - Венгрии и Польши. Конституционный Суд Венгерской Республики рассматривал вопрос аборта дважды, и в каждом случае

20 Постановление Конституционного Суда РФ от 2 февраля 1999 г. № 3-П по делу о проверке конституционности положений статьи 41 и части третьей статьи 42 УПК РСФСР, пунктов 1 и 2 Постановления Верховного Совета Российской Федерации от 16 июля 1993 года «О порядке введения в действие Закона Российской Федерации «О внесении изменений и дополнений в Закон РСФСР «О судоустройстве РСФСР», Уголовно - процессуальный кодекс РСФСР, Уголовный кодекс РСФСР и Кодекс РСФСР об административных правонарушениях» в связи с запросом Московского городского суда и жалобами ряда граждан // Собрание законодательства Российской Федерации. 1999. № 6. Ст. 867.

21 Определение Конституционного Суда РФ от 19 ноября 2009 г. № 1344-О-Р о разъяснении пункта 5 резолютивной части Постановления Конституционного Суда Российской Федерации от 2 февраля 1999 года № 3-П по делу о проверке конституционности положений статьи 41 и части третьей статьи 42 Уголовно-процессуального кодекса РСФСР, пунктов 1 и 2 Постановления Верховного Совета Российской Федерации от 16 июля 1993 года «О порядке введения в действие Закона Российской Федерации «О внесении изменений и дополнений в Закон РСФСР «О судоустройстве РСФСР», Уголовно-процессуальный кодекс РСФСР, Уголовный кодекс РСФСР и Кодекс РСФСР об административных правонарушениях // Собрание законодательства Российской Федерации. 2009. № 48. Ст. 5867. он значительно ограничивал полномочия органов законодательной власти ${ }^{22}$. Так, в решении Конституционного Суда Венгрии 64/1991 от 17 декабря 1991 г. была установлена неконституционность существующего на тот момент относительно либерального законодательства об абортах, на том основании, что эти отношения должны регулироваться законами, принятыми Парламентом, а не подзаконными актами Министерства здравоохранения. Вместе с тем, отрицая правоспособность плода, Конституционный Суд постановил, что разрешение аборта не будет удовлетворительным решением, поскольку что «право плода на жизнь - в действительности его право родиться - не может быть поставлено в зависимость от факта рождения» ${ }^{23}$. Таким образом, Суд признал нерожденного ребенка в качестве субъекта конституционного права, постановил, что право на жизнь начинается не с момента рождения, а с момента зачатия.

Конституционный Суд Венгерской Республики повторно рассмотрел проблему аборта в ноябре 1998 г. $^{24}$ В этом решении Суд постановил, что прерывание беременности, основанное на «чрезвычайной ситуации» является вполне конституционным. Конституционный Суд ограничил допустимость аборта определенным крайне узким кругом экстраординарных случаев - угрозы жизни или здоровью матери, и т.д. Право выбора женщины было в значительной степени ограничено. Не удивительно, что большая часть ученых согласилась с мнением о том, что данное решение Конституционного Суда приведет к ограничению предварительно либеральных методов в вопросе о разрешении абортов 25 .

22 Шеппели К.Л. Права женщин в странах Восточной Европы // Конституционное право: восточноевропейское обозрение. 1995. № 1. С. 30.

23 Решение Конституционного Суда Венгерской Республики 64/1991 от 17 декабря 1991 г. / Decision 64/1991 of 17 December 1991 // Интернет-сайт Конституционного Суда Венгерской Республики. http://www.mkab.hu.

24 Решение Конституционного Суда Венгерской Республики 48/1998 от 23 ноября 1998 г. / Decision 48/1998 of 23 November 1998. // Bulletin on Constitutional Case Law. 1998. N. 3. P. $421-422$.

25 Constitution Watch: Hungary // East European Constitutional Review. Fall 1998. Vol. 7. № 4. Р. 17. См. также: Уитц Р. Привлечение судов к суду: история соблюдения Венгрией стандартов Европейского Суда по правам человека // Имплементация решений Европейского Суда по правам человека в практике конституционных судов стран Европы. Сборник докладов. М., 2006. С. 61. 
Конституционный Трибунал Республики Польской неоднократно рассматривал проблему абортов. Первый раз - в начале 1991 г., когда Уполномоченный по правам граждан направил в Трибунал запрос о проверке законности декрета Министра здравоохранения от 30 апреля 1990 г., устанавливающего право врача отказаться произвести аборт ${ }^{26}$. Трибунал признал подзаконный акт министра соответствующим закону, и совместимым с конституционным правом на свободу совести. В решении было установлено, что право врача отказаться выполнять такие действия проистекает из конституционного права на свободу совести, а так же из «Кодекса врачебной этики», который обязывает врача отказаться от врачебных манипуляций, которые, по его мнению, являются вредными или неэтичными. Трибунал объявил: «Запрет аборта является первичным, и Закон от 27 апреля 1956 г. только определяет условия допустимых исключений из этого положения».

В 1992 г. Уполномоченный по правам граждан направил в Конституционный Трибунал жалобу об устранении возможной коллизии между «Кодексом врачебной этики», с Уголовным кодексом и с Законом «Об абортах» ${ }^{27}$. Поправки к «Кодексу медицинской этики» установили право врача выполнить аборт в случаях наступления беременности в результате изнасилования, а также, если беременность представляет прямую угрозу жизни или здоровью женщины, тогда как закон об абортах предусмотрел допустимость аборта также в случае «трудных условий жизни беременной женщины». Повторяя ранее высказанную правовую позицию, Трибунал заявил, что Закон «Об абортах» 1956 г. «не устанавливает обязанность врача производить аборты, он исключает применение судом мер юридической ответственности за проведение абортов в случаях, установленных в законе». Следовательно, отсутствует коллизия между Законом «Об абортах» и «Кодексом медицинской этики».

Наконец, самое важное решение было принято 28 мая $1997 \Gamma^{28}$. В этом решении, Трибунал призна-

\footnotetext{
26 Решение Конституционного Трибунала Республики Польской U. 8/90 от 15 января 1991 г. / Decision U. 8/90 of 15 January 1991. // Интернет-сайт Конституционного Трибунала Республики Польской. http://www.trybunal.gov.pl.

27 Решение Конституционного Трибунала Республики Польской U. 1/92 от 7 октября 1992 г. / Decision U.1/92 of 7 October 1992 // Интернет-сайт Конституционного Трибунала Республики Польской. http://www.trybunal.gov.pl.

28 Решение Конституционного Трибунала Республики Польской К 26/96 от 28 мая 1997 г./ Decision K 26/96 of 28
}

вал неконституционными нормы закона, разрешающие аборт при трудных финансовых и личных обстоятельствах, как установлено в Законе от 30 августа 1996 г. Центральным основанием для этого решения был принцип правового государства, которое провозглашает человека и его жизнь в качестве высшей ценности. Это положение, как установило большинство судей, является основанием для признания неконституционными норм права, допускающих аборт на основании трудных финансовых и личных обстоятельств. Следует отметить, что из всех решений польского Конституционного Трибунала, а может быть и из всех конституционных судов государств Центральной и Восточной Европе, это решение было самым очевидным случаем узурпации Судом полномочия по изданию законов. Вопреки явному волеизъявлению большинства законодателей, при полном отсутствии каких-либо оснований в тексте Конституции («право на жизнь» не было в явном виде закреплено в тексте конституции, действовавшей на момент принятия решения), и с ясными признаками того, что в тексте принятой, но не вступившей в силу, конституции «право на жизнь» не рассматривается как «право на жизнь с момента зачатия», Трибунал принял решение большого общественного значения, которое поставило вне закона почти все виды абортов. На это польский философ Я. Волинский заметил: «Трибунал поднял его собственное недостаточно ясно сформулированное целеполагание до уровня юридического принципа, ... что не входит в компетенцию Трибунала» ${ }^{29}$. Особенно неутешительно, что не только резолютивная, но и мотивировочная части, являются запутанными и имеют все признаки необоснованного решения.

Еще одним случаем защиты права на жизнь в практике Конституционного Суда Венгерской Республики является решение № 22/2003 от 28 апреля $2003 \Gamma^{30}$ В этом деле Конституционный суд не признал не соответствующей Конституции эвтаназию как таковую, но решительно отклонил толкование нормы Закона «Об охране здоровья»,

May 1997. // East European Case Reporter of Constitutional Law 1999. Vol. 6. P. 38-129.

29 Цит. по: Sadurski W. Rights Before Courts: A Study of Constitutional Courts in Postcommunist States of Central and Eastern Europe. P. 135.

30 Решение Конституционного Суда Венгерской Республики 22/2003 от 28 апреля 2003 г. / Decision 22/2003 of 28 April 2003// Интернет-сайт Конституционного Суда Венгерской Республики. http://www.mkab.hu. 
закрепляющей право пациентов на самоопределение как допускающее активную эвтаназию. В этом деле Суд объяснил взаимосвязь между правом на жизнь и правом на человеческое достоинство и допустимыми их ограничениями. Хотя Суд признал, что требование об активной эвтаназии не является требованием о лишении жизни одного человека другим, а представляет собой решение о самоубийстве, для претворения которого в жизнь требуется помощь другого человека. Конституционный Суд постановил, что в случае с эвтаназией право на достоинство личности и его составная часть - право на автономию (самоопределение) не является неприкосновенным и подлежит таким же ограничениям, как и любое другое конституционное право. В случае эвтаназии ограничения, налагаемые на право на самоопределение, вытекают из обязанности государства защищать жизнь человека (ч. $1 \S$ 8 Конституции Венгерской Республики). В основе правовой позиции Конституционного Суда лежит представление о человеке, который нуждается в защите от последствий своих решений с помощью государства, действующего исключительно в интересах этого человека.

Изложенное позволяет сделать следующие выводы.

1. При рассмотрении дел о проверке конституционности законов, разрешающих применение смертной казни как исключительной меры наказания, органы конституционной юстиции исходят из приоритета человеческой жизни как высшей ценности, в том числе, в сравнении с целями обеспечения законности и правопорядка в конкретном государстве. Анализ практики конституционных судов государств Центральной и Восточной Европы показывает, что они инициировали отмену смертной казни в Албании, Венгрии, Литве и Украине. Система решений Конституционного Суда РФ привела к тому, что в Российской Федерации сложился легитимный конституционно-правовой режим, в который включается комплексный мораторий на применение смертной казни.
При этом конституционные суды при вынесении решений о запрещении смертной казни и утверждении неограниченного права на жизнь основывались не столько на нормах национальных конституций, сколько на международных стандартах защиты права на жизнь, международно-правовой тенденции запрещения смертной казни и политических обязательств, взятых на себя конкретным государством.

2. Несмотря на содержащиеся в конституциях большинства государств положения о равной юридической силе конституционных норм, закрепляющих личные (гражданские) права, а также об их равной юридической защите, конституционные суды отдают явное предпочтение защите права на жизнь в сравнении с другими личными (гражданскими) правами и свободами. Это наиболее ярко проявляется в практике судебных органов конституционного контроля Венгерской Республики и Республики Польской, которые утверждают приоритет права на жизнь «от зачатия, а не от рождения» и его усиленную защиту со стороны государства в сравнении с достоинством личности (в аспекте права женщины на физическое самоопределение) и права на неприкосновенность частной жизни при проверке конституционности нормативных правовых актов, разрешающих осуществление абортов. Конституционный Суд Венгерской Республики при рассмотрении дела о проверке конституционности Закона «Об охране здоровья», постановил, что право на достоинство личности и его составная часть право на самоопределение - не является абсолютным. Ограничения, налагаемые на данное право, вытекают из обязанности государства защищать жизнь человека даже против желания самого субъекта этого права.

3. Решения, принятые судебными органами конституционного контроля как в Российской Федерации, так и в государствах Центральной и Восточной Европы, значительно изменяют содержание норм основных законов этих стран, расширяя их содержание.

\section{Библиография:}

1. Витрук Н.В. Конституционное правосудие: учебное пособие. М., 2005.

2. Конституции государств Европы. В 3 т. / Под общ. ред. Л.А. Окунькова. М., 2001.

3. Коротеев К. Мотивировки решений конституционных судов о смертной казни // Сравнительное конституционное обозрение. 2008. № 5 (66).

4. Шеппели К.Л. Права женщин в странах Восточной Европы // Конституционное право: восточноевропейское обозрение. 1995. № 1. 
5. Уитц Р. Привлечение судов к суду: история соблюдения Венгрией стандартов Европейского Суда по правам человека // Имплементация решений Европейского Суда по правам человека в практике конституционных судов стран Европы. Сборник докладов. М., 2006.

6. Hollander. P. The Role of Czech Constitutional Court: Application of the Constitution in Case Decision of Ordinary Courts // Parker School journal of East European law. 1997. Vol.

7. Fijalkowski A. The Abolition of the Death Penalty in Central and Eastern Europe // Tilburg Foreign Law Review. 2001. Vol. 9.

8. Sóyom L. The Role of Constitutional Courts in the Transition to Democracy: With Special Reference to Hungary // International Sociology. Vol. 1. 2003. No. 1.

9. Schwartz H. The Struggle for Constitutional Justice in Post-Communist Europe, Chicago, 2000.

10. Visser M. de Constitutional Review in Europe. A Comparative Analysis. Oregon, 2014.

11. Шовкринский А.Ю. Виды оснований для исключений из нормы об исчерпании внутренних средств правовой защиты, признанных в международном праве // NB: Вопросы права и политики. - 2014. - 5. - C. 69 - 91. DOI: 10.7256/2305-9699.2014.5.11876. URL: http://www.e-notabene.ru/lr/article_11876.html

12. Клинке У. Развитие юрисдикции Суда Европейского Союза // Журнал зарубежного законодательства и сравнительного правоведения. - 2012. - 6. - С. 57 - 69.

13. Можуга В.В. Юридическая природа решений Конституционного суда Российской Федерации в их соотношении с решениями суда ЕврАзЭС // Право и политика. - 2014. - 1. - C. 37 - 41. DOI: 10.7256/1811-9018.2014.1.10647.

\section{References (transliterated):}

1. Vitruk N.V. Konstitutsionnoe pravosudie: uchebnoe posobie. M., 2005.

2. Konstitutsii gosudarstv Evropy. V 3 t. / Pod obshch. red. L.A. Okun'kova. M., 2001.

3. Koroteev K. Motivirovki reshenii konstitutsionnykh sudov o smertnoi kazni // Sravnitel'noe konstitutsionnoe obozrenie. 2008. № 5 (66).

4. Sheppeli K.L. Prava zhenshchin v stranakh Vostochnoi Evropy // Konstitutsionnoe pravo: vostochnoevropeiskoe obozrenie. 1995. № 1.

5. Uitts R. Privlechenie sudov k sudu: istoriya soblyudeniya Vengriei standartov Evropeiskogo Suda po pravam cheloveka // Implementatsiya reshenii Evropeiskogo Suda po pravam cheloveka v praktike konstitutsionnykh sudov stran Evropy. Sbornik dokladov. M., 2006.

6. Hollander. P. The Role of Czech Constitutional Court: Application of the Constitution in Case Decision of Ordinary Courts // Parker School journal of East European law. 1997. Vol.

7. Fijalkowski A. The Abolition of the Death Penalty in Central and Eastern Europe // Tilburg Foreign Law Review. 2001. Vol. 9.

8. Sóyom L. The Role of Constitutional Courts in the Transition to Democracy: With Special Reference to Hungary // International Sociology. Vol. 1. 2003. No. 1.

9. Schwartz H. The Struggle for Constitutional Justice in Post-Communist Europe, Chicago, 2000.

10. Visser M. de Constitutional Review in Europe. A Comparative Analysis. Oregon, 2014.

11. Shovkrinskii A.Yu. Vidy osnovanii dlya isklyuchenii iz normy ob ischerpanii vnutrennikh sredstv pravovoi zashchity, priznannykh v mezhdunarodnom prave // NB: Voprosy prava i politiki. - 2014. - 5. - C. 69 - 91. DOI: 10.7256/23059699.2014.5.11876. URL: http://www.e-notabene.ru/lr/article_11876.html

12. Klinke U. Razvitie yurisdiktsii Suda Evropeiskogo Soyuza // Zhurnal zarubezhnogo zakonodatel'stva i sravnitel'nogo pravovedeniya. - 2012. - 6. - C. $57-69$.

13. Mozhuga V.V. Yuridicheskaya priroda reshenii Konstitutsionnogo suda Rossiiskoi Federatsii v ikh sootnoshenii s resheniyami suda EvrAzES // Pravo i politika. - 2014. - 1. - C. 37 - 41. DOI: 10.7256/1811-9018.2014.1.10647. 